\title{
Physical and psychological violence in dating with stress among adolescents during the COVID-19 pandemic
}

\author{
Suci Musvita Ayu, Liena Sofiana, Nurul Karina Sabrina \\ Faculty of Public Health, Universitas Ahmad Dahlan, Indonesia
}

\begin{tabular}{l}
\hline \hline Article Info \\
\hline Article history: \\
Received Nov 30, 2020 \\
Revised May 22, 2021 \\
Accepted Jun 13, 2021 \\
\hline
\end{tabular}

Keywords:

Dating

Physical violence

Psychological violence

Stress

Teenagers

\begin{abstract}
Currently, the juvenile delinquency trend is still very high. Dating violence (DV) is one of the delinquencies that teenagers often commit. DV has negative impacts in the form of physical and psychological impacts. Physical impacts can include bruises, fractures. Meanwhile, the psychological impact can be a the form of depression, stress, anxiety, and sleep problems. This study aimed to analyze the relationship between physical and psychological violence in dating stress adolescents. This study used a cross-sectional design. Sample of this study was 314 students (15-19 years) in Bantul chosen through a purposive sampling technique. Data analysis was using multiple logistic regressions. The results showed that there was a significant relationship towards stress, namely gender (pvalue $=0.050)$, physical violence $(\mathrm{p}$-value $=0.000)$, and psychological violence $(p$-value $=0.000)$. Age $(p$-value $=0.653)$ and parents' income (p-value $=0.100)$ had no significant relationship to stress. Psychological violence variable ( $\mathrm{p}$-value $=0.000 ; \mathrm{OR}=6.285,95 \%$; $\mathrm{CI}=3.683-10.726$ ) was the most dominant in triggering stress in adolescents. So, there were relationships between gender, physical and psychological violence in dating with the incidence of stress among adolescents in Bantul Regency, Yogyakarta, Indonesia during the COVID-19 pandemic.
\end{abstract}

This is an open access article under the CC BY-SA license.

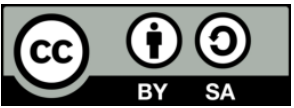

\section{Corresponding Author:}

Suci Musvita Ayu

Faculty of Public Health

Universitas Ahmad Dahlan

Jl. Prof. Dr. Soepomo, Janturan, Yogyakarta (55164), Indonesia

Email: suci.ayu@ikm.uad.ac.id

\section{INTRODUCTION}

Dating violence (DV) is a phenomenon that often occurs around us. DV is still everywhere regardless of origin, ethnicity and region [1]. Nearly one-third of women in the world who are in a relationship have experienced physical or sexual violence by their partner [2]. Violence has a direct impact on women's health. In some cases, violence can even be fatal.

Consequently, physical and mental health can also have a lasting effect even after the violence has stopped [3]. Partner violence is one of the most painful and traumatic experiences because it destroys interpersonal trust and a sense of security [4]. DV that often occurs in adolescents usually in the form of physical, economic, psychological, mental, and sexual violence. Physical DV can include kicking, hitting, and pinching. In the mental structure of excessive jealousy, coercion, and harsh treatment in public. In the 
economic form, dating violence can be in the form of the perpetrator borrowing money or goods without ever returning it. Violence in the form of psychology, for example, insults, comparing one's partner with others, and excessive jealousy. Meanwhile, violence in the form of sexuality can be in the form of coercion to have sexual relations, rape or other acts [5].

Dating violence occurs widely in Indonesia. The Ministry of Women's and Children's Empowerment stated that $42.7 \%$ of unmarried women had experienced violence, and 2,090 of the 10,847 perpetrators of violence are boyfriends/friends [6]. According to the Annual Record (CATAHU) in 2017, there were 1,873 cases of violence and an increase of 200 cases in 2018 [7]. The women empowerment service for child protection and family planning (DP3AKB) reported that the DV rate reached 703 cases, while in district courts, there were 216 cases. According to CATAHU, the age characteristics of DV victims are in the range of 13-18 years, and the perpetrators are 19-24 years [7]. The age of 13-18 years, many of them are victims of dating violence because of the average age of dating adolescents. They tend to have dating relationships at that age.

In 2018, there were 980 cases of violence against women in the Special Region of Yogyakarta and was ranked sixth in Indonesia. In 2015 in Bantul District, there were 90 cases of violence against women, then increased to 94 cases in 2016 and 131 cases in 2017 [7].There were 74 cases of dating violence in Bantul Regency in 2017 and an increase of 80 cases in 2018 [8]. According to previous research, there were $30.83 \%$ of young women who experienced physical violence. A total of $34.17 \%$ participated in sexual violence, namely kissing forcibly. The $25.85 \%$ of young women experience economic violence because they have to buy phone credit for their boyfriend/partner. The $17.50 \%$ experienced emotional violence because their boyfriend/partner made them laugh [9].

In the current pandemic era, we are required to work and learn from home, teenagers/students are no exception. Adolescents become social restrictions and tend to only do activities at home.Dating adolescents were also targeted in this study because couples were more likely to interrogate the activities that the partner was doing, more often asked what they were doing, with whom, and so on. This makes the partner uncomfortable in the relationship, because he feels intimidated or restrained (possessive). The impact of violence in dating in various ways, ranging from being too possessive, easily jealous, committing physical violence, such as hitting, pushing, or slapping, even to having sexual relations and murder. So far the government has made various efforts to reduce the number of violence that has occurred, starting from cooperation in the social sector, psychiatry and the police. but because this phenomenon is like an iceberg phenomenon so it must be done more closely or in-depth interviews to be able to uncover the problem [9].

\section{RESEARCH METHOD}

This research was a purposive sampling technique and design is a cross-sectional approach. The research population used was 32,815 students at the high school level in Bantul Regency. The numbers of samples were 314 students. The sample inclusion criteria were students aged 15-19 years and already or currently dating. In contrast, the exclusion criteria were unwillingness to become respondents, students who had never been dating and students who did not fill the questionnaire.

Identification of the relationship between the variables of age, gender, parental income, physical and psychological violence and stress events using bivariate analysis. Odds ratioand hypothesis testing used the Chi-square statistic at the 5\% significance level. Multivariate analysis used multiple logistic regressions to produce an adjusted odds ratio.

\section{RESULTS AND DISCUSSION}

\subsection{Respondent characteristics}

Table 1 describes the frequency distribution of characteristics of high school students in Bantul Regency, Yogyakarta, Indonesia Most of the respondents were 15-16 years old. Most of the respondents are female. There were $34 \%$ of respondents come from 10th grade, and more than $58 \%$ of respondents have parental income with category $\leq 124,85$ USD or IDR $1,750,500$.

\subsection{Univariate analysis}

Table 2 shows that all respondents have experienced physical and psychological violence. Most of the respondents of the study were experienced in the low category of physical violence. In the psychological violence variable, respondents experienced violence in the High category. The level of stress in the Low category of respondents was $6.4 \%$ higher than the High category.

Table 3 and Table 4 describe the forms of physical and psychological violence experienced by adolescents. Based on Table 3, the most frequent physical violence experienced by adolescents is "pushed or pulled" with a percentage of around $16 \%$. The rare act of violence was "clothes being torn off and beating or 
slapping" with a portion of $6 \%$ each. Based on Table 4, the psychological violence most often experienced by adolescents is to bring up the past with a percentage of $7 \%$. Meanwhile, the least amount of psychological violence was Forcing to have sex with a ratio of $3 \%$.

Table 1. Demographics of respondents

\begin{tabular}{lcc}
\hline \multicolumn{1}{c}{ Characteristics } & Frequency $(\mathrm{n})$ & Percent $(\%)$ \\
\hline Age (years) & 172 & 54.8 \\
$15-16$ & 142 & 45.2 \\
$17-18$ & & \\
Gender & 241 & 76.8 \\
$\quad$ Female & 73 & 23.2 \\
$\quad$ Male & & \\
Grade & 107 & 34.1 \\
$10^{\text {th }}$ & 106 & 33.8 \\
$11^{\text {th }}$ & 101 & 32.2 \\
$12^{\text {th }}$ & & \\
Parents' income (IDR) & 183 & 58.3 \\
$\quad \leq 124,85$ USD (1,750,500) & 131 & 41.7 \\
$\quad>124,85$ USD $(1,750,500)$ & 314 & 100 \\
Total & & \\
\hline
\end{tabular}

Table 2. Univariate analysis

\begin{tabular}{lcc}
\hline \multicolumn{1}{c}{ Variable } & Frequency $(\mathrm{n})$ & Percent $(\%)$ \\
\hline Physical Violence & & \\
High & 109 & 34.7 \\
Low & 205 & 65.3 \\
Psychological Violence & & \\
High & 140 & 44.6 \\
Low & 174 & 55.4 \\
Stress & & \\
High & 147 & 46.8 \\
Low & 167 & 53.2 \\
Total & 314 & 100 \\
\hline
\end{tabular}

Table 3. Physical violence in adolescents

\begin{tabular}{lcc}
\hline Physical violence & Frequency $(\mathrm{n})$ & Percent $(\%)$ \\
\hline Hit or punch & 67 & 7 \\
Slap & 59 & 6 \\
Scratching & 71 & 8 \\
Hand twist & 74 & 8 \\
Slamming & 74 & 8 \\
Push or pull & 154 & 16 \\
Bite & 75 & 8 \\
Suffocate & 76 & 8 \\
Forcing off the vehicle & 98 & 10 \\
Injuring with a hard object & 73 & 8 \\
Tearing clothes & 57 & 6 \\
Forcing to have sex & 62 & 7
\end{tabular}

Table 4. Psychological violence in adolescents

\begin{tabular}{lcc}
\hline Psychological Violence & Frequency (N) & Percent (\%) \\
\hline Underestimating & 210 & 4 \\
Demanding obedience & 273 & 6 \\
Angry when reprimanded & 238 & 5 \\
Demanding sexual intercourse & 155 & 3 \\
Limiting association & 301 & 6 \\
Limiting friends of the opposite sex & 263 & 6 \\
Scolding in front of others & 225 & 5 \\
Stingy & 229 & 5 \\
Underestimating academic abilities & 226 & 5 \\
Yelling and shouting & 224 & 5 \\
Disrespect feelings & 278 & 6 \\
Make fear & 237 & 5 \\
Treat it like a fool & 221 & 5 \\
Rough & 240 & 5 \\
Mocking appearance & 219 & 5 \\
Threatening & 222 & 5 \\
Bring up the past & 308 & 7 \\
Insulting in front of friends & 202 & 4 \\
Scare & 207 & 4 \\
Saying hurtful things & 256 & 5 \\
\hline
\end{tabular}

\subsection{Bivariate analysis}

Table 5 describes the results of the bivariate test. The results of the chi-square test showed that adolescents aged 15-16 years, and respondents who had parents with an income $\leq 124,85$ USD (IDR $1,750,500)$ experienced low stress. However, the stress levels on these two variables were not statistically significant. Based on gender, female respondents experienced stress in the low category, and it was statistically significant. Respondents who experienced both physical and psychological violence have a high level of stress and statistical significance.

Physical and psychological violence in dating with stress among adolescents... (Suci Musvita Ayu) 
Table 5. Bivariate analysis

\begin{tabular}{|c|c|c|c|c|c|c|c|}
\hline \multicolumn{8}{|c|}{ Stress } \\
\hline \multirow[t]{2}{*}{ Variable } & \multicolumn{2}{|c|}{ High } & \multicolumn{2}{|c|}{ Low } & \multirow{2}{*}{ Total } & \multirow[t]{2}{*}{ p-value } & \multirow[t]{2}{*}{ OR CI $95 \%$} \\
\hline & $\mathrm{n}$ & $(\%)$ & $\mathrm{n}$ & $(\%)$ & & & \\
\hline \multicolumn{8}{|l|}{ Age (years) } \\
\hline $15-16$ & 83 & 48.3 & 89 & 51.7 & 172 & \multirow{2}{*}{0.653} & \multirow{2}{*}{$1.137(0.728-1.775)$} \\
\hline $17-19$ & 64 & 45.0 & 78 & 55.0 & 142 & & \\
\hline \multicolumn{8}{|l|}{ Gender } \\
\hline Female & 105 & 43.6 & 136 & 57.4 & 241 & \multirow{2}{*}{0.050} & \multirow{2}{*}{$0.570(0.336-0.968)$} \\
\hline Male & 42 & 57.5 & 31 & 42.4 & 73 & & \\
\hline \multicolumn{8}{|l|}{ Parents' Income (IDR) } \\
\hline$\leq 124.85$ USD (Rp. 1.750 .500$)$ & 78 & 42.6 & 105 & 57.3 & 183 & \multirow{2}{*}{0.100} & \multirow{2}{*}{$0.667(0.425-1.048)$} \\
\hline$>124.85$ USD (Rp. 1.750 .500$)$ & 69 & 52.6 & 62 & 47.4 & 131 & & \\
\hline \multicolumn{8}{|l|}{ Physical Violence } \\
\hline High & 73 & 66.9 & 36 & 33.1 & 109 & \multirow{2}{*}{0.000} & \multirow{2}{*}{$3.590(2.198-5.862)$} \\
\hline Low & 74 & 36.0 & 131 & 64.0 & 205 & & \\
\hline \multicolumn{8}{|l|}{ Psychological Violence } \\
\hline High & 100 & 71.4 & 40 & 28.6 & 140 & \multirow{3}{*}{0.000} & \multirow{3}{*}{$6.755(4.112-11.098)$} \\
\hline Low & 47 & 27.0 & 127 & 73.0 & 174 & & \\
\hline Total & & & & & 314 & & \\
\hline
\end{tabular}

\subsection{Multivariate analysis}

Table 6 describes the results of the multivariate test using logistic regression analysis. This table shows that Psychological violence variable ( $\mathrm{p}$-value $=0.000 ; \mathrm{OR}=6.285,95 \% ; \mathrm{CI}=3.683-10.726$ ) was the most dominant in triggering stress in adolescents.

Table 6. Results of multivariate analysis (Logistic regression)

\begin{tabular}{|c|c|c|c|c|c|}
\hline \multirow[b]{2}{*}{ Variable } & \multicolumn{3}{|c|}{ Stress } & \multicolumn{2}{|c|}{ Odds Ratio $(95 \% \mathrm{CI})$} \\
\hline & $\begin{array}{l}\text { High } \\
(\%)\end{array}$ & $\begin{array}{c}\text { Low } \\
(\%)\end{array}$ & $\begin{array}{l}\text { Total } \\
\text { (n) }\end{array}$ & Unadjusted & Adjusted \\
\hline \multicolumn{6}{|l|}{ Age (years) } \\
\hline $15-16$ & 48.3 & 51.7 & 172 & & \\
\hline $17-19$ & 45.0 & 55.0 & 142 & $1.137[0.728-1.775]$ & $1.615[0.953-2.737]$ \\
\hline \multicolumn{6}{|l|}{ Gender } \\
\hline Female & 43.6 & 57.4 & 241 & & \\
\hline Male & 57.5 & 42.4 & 73 & $0.570[0.336-0.968]$ & $0.520[0.282-0.958]$ \\
\hline \multicolumn{6}{|l|}{ Parents' Income } \\
\hline$\leq 124,85$ USD (IDR $1,750,500)$ & 42.6 & 57.3 & 183 & & \\
\hline$>124,85$ USD (IDR $1,750,500)$ & 52.6 & 47.4 & 131 & $0.667[0.425-1.048]$ & $0.852[0.504-1.439]$ \\
\hline \multicolumn{6}{|l|}{ Physical Violence } \\
\hline High & 66.9 & 33.1 & 109 & & \\
\hline Low & 36.0 & 64.0 & 205 & $3.590[2.198-5.862]$ & $2.655[1.540-4.578]$ \\
\hline \multicolumn{6}{|l|}{ Psychological Violence } \\
\hline High & 71.4 & 28.6 & 140 & & \\
\hline Low & 27.0 & 73.0 & 174 & $6.755[4.112-11.098]$ & $6.285[3.683-10.726]$ \\
\hline Total & & & 314 & & \\
\hline
\end{tabular}

\subsubsection{Relationship between age and stress}

Based on Table 6, after adjusting, the OR value of the age variable has increased from 1.137 to 1.615. Thus, adolescents aged 15-16 years were 1.615 times more likely to experience stress but it was not statistically significant $(\mathrm{AOR}=1.615 ; \mathrm{CI}=0.953-2.737 ; \mathrm{p}$-value $=0.643)$. Adolescents who are still underage show a tendency to behave as desired. At this stage, adolescents are more relaxed in doing activities or at will, so they tend not to get stressed easily. Especially amid the current pandemic, students are working on assignments from home and tend to be more relaxed. So that there is no coercion or deadline to make them depressed.

This study is in line with research by [10], which states that age does not have a significant effect on stress $(\mathrm{p}=0.382)$. However, Dosil [11] found that age affects the incidence of violence. Suwartika et al., [12] stated that there is a relationship between age and the incidence of stress in adolescents with a value of $\mathrm{p}=0.039$. The reason is that as an adult, someone is usually more skilled at managing stress than adolescents and the elderly. The causes of stress in adolescents are various, one of which is the social environment of the individual. Psychosocial stressors are stress caused by social, environmental stressors [13]. 


\subsubsection{Relationship between gender and stress}

The OR value on the gender variable has decreased from 0.570 to 0.520 . Thus, adolescent girls have a 0.520 times greater chance of experiencing stress and this is statistically significant (AOR=0.520; $\mathrm{CI}=0.282-0.958$; $\mathrm{p}$-value $=0.050$ ). Researchers assume that women are more prone to experiencing stress because women tend to be more thinkers than men; women are more likely to think about a problem excessively and make it vulnerable to stress. Besides, women's lives, in general, are greatly influenced by their romantic relationships, so that when problems arise in their relationships, women are more prone to experiencing stress than men.

This research is in line with research conducted by Nasrani andPurnawati, which states that women are more likely to experience stress, which causes anxiety and fear [12]. According toHafifah, sex differences affect the incidence of stress [14]. Women express more of what happens to them selves. At the same time, men prefer to control their emotions, accept the problems they are experiencing, do not think about stressful situations, and make efforts to solve a problem. Violence is related to the gender of adolescents, apart from that the parenting factor is also significant [15]. Women have a tendency to accept treatment, do not consider the violence they experience to be something to be avoided, they also consider men to be stronger than women.

Relationship between Parents' income and stressstatistically, the parents' income has no significant relationship with stress. However, adolescents with parental income $\leq 124,85$ USD (IDR 1,750,500) have a 0.852 times greater chance of experiencing stress than adolescents with parental income $>124,85$ USD (IDR1,750,500). In this situation, adolescents tend to want to show their identity in everything, including in economic terms. Teens look for ways to meet their needs, even with the consequences they have to work. When they get what they want, they will feel calmer and stress-free. These findings reinforce the resultswhich found a meaningless relationship between parental income and stress levels in adolescents [14]. Respondents who have low income have a lower chance of experiencing stress than those with high income [16]. Respondents who have low income focus on their needs and interests in fulfilling their daily lives. While those who have high incomes focus on the environment and always want to keep updating according to the times. This study contrasts found that there is a significant relationship between stress and income levels [17]. Expenditures more significant than income will trigger stress in family members [18].

\subsubsection{Relationship between physical violence and stress}

The OR value on the physical violence variable has decreased from 3.590 to 2.655 . So that adolescents who experience low physical violence have a 2.655 times greater chance of experiencing stress and it is statistically significant $(\mathrm{AOR}=2.655 ; \mathrm{CI}=1.540-4.578$; $\mathrm{p}$-value=0.000). The reality shows that even though the dominant teenager experiences violence at a low level, there is still the potential for violence in the high category. Adolescents consider the treatment-experienced is trivial or natural. So that it seems that he allows the treatment to be experienced repeatedly without any anticipation for him. During a pandemic like this, there are still many cases of physical violence in dating. Even though they are doing social distancing, there are still many teenagers who meet their boyfriends/partners, although not as often as usual. Due to the reduced frequency of meetings, it makes teenagers more emotional, suspicious, and possessive, feels less cared for by their boyfriends, and becomes jealous more easily. These feelings can lead to physical violence when they meet. For example, during a pandemic like this, teenagers do more activities on social media, such as Tik-Tok, Instagram, and Twitter, Facebook and WhatsApp, where all social media users can like and comment on posts they make. This situation makes the perpetrator feel jealous of his girlfriend/partner who interacts with the opposite sex. Thus triggering physical violence against victims.

These findings are in line with research violence often occurs among dating partners, but they do not consider it a serious or even avoided problem [19]. Women are more likely to commit acts of physical violence to their partners [20]. Physical violence in the mild category significantly increases depression, anxiety, and post-traumatic stress disorder (PTSD). Research conducted shows that there is a significant relationship between physical violence experienced by respondents at work and the incidence of work stress [21]. Respondents who experienced physical violence from a partner, $144(79.6 \%)$ reported that they experienced verbal abuse and researchers found that physical violence received was related to the incidence of stress in workers [22].

\subsubsection{Relationship between psychological violence and stress}

The OR value for psychological violence decreased from 6.755 to 6.285 . Thus, adolescents who experienced severe psychological violence were 6.285 times more likely to experience stress and it was statistically significant $(\mathrm{AOR}=6.285 ; \mathrm{CI}=3.683-10.726$; $\mathrm{p}$-value=0.000). In times of pandemics like now, couples who initially had close relationships turned into long-distance relationships. As a result, there is a reduction in meeting frequency directly. This triggers the partner always to overthink and tends to think 
about things that are not sure which can lead to negative perceptions. Due to limited communication due to the pandemic, partners tend to be more irritable, become more jealous and possessive. Moreover, worse, there is an assumption that they experience it naturally as an expression of affection for their partner.

According to the Perkumpulan Keluarga Berencana Indonesia (PKBI) [23], psychological violence in dating is the most common occurrence during the COVID-19 pandemic. Social restrictions that occurred during the pandemic made violence easy for adolescents, especially psychological violence. Psychological violence in dating is often not realized by victims and perpetrators because they feel that it is a manifestation of love for their partners [24]. According to Kemenpppa [8], violence in dating generally occurs because the victim does not feel or know that the act committed by his partner is an act of violence. So they consider it a sign of affection and fairness. Psychological violence in dating has a psychological impact on adolescents such as fear, closing themselves off from the outside world, stress, decreased academic grades, lazy activities, heartache, the crisis of trust in others, trauma, and anger.

This psychological impact is in line with the results of Safitriresearch that violence in dating, psychological, physical, and sexual violence can have an impact on the emergence of stress on the victim [25]. According to victims of DV, become afraid, cry, have trouble sleeping, hate men, and raise suspicion against men [26]. This incident shows that every act of violence has a positive correlation with the mental health of victims of violence (anxiety, depression, stress, and suicide). The results of this study are in line with the reports ofcommunication difficulties, and self-defenceis factored in the occurrence of violence in boyfriends among adolescents [23], [27]. Even psychological violence is associated with an increase in suicide attempts in boys and girls [25].

\section{CONCLUSION}

Based on the results of the analysis and previous discussion, the incidence of stress is related to gender, the incidence of physical and psychological violence in adolescents. The multivariate analysis shows that the most dominant factor that triggers stress in adolescents is psychological violence. Younger age is more prone to experience stress by 1.615 times, and it is not significant. Women have the opportunity to experience stress 0.520 times, and it is statistically significant. Low income of parents is more prone to stress by 0.852 times, and it is not statistically significant. Physical and psychological violence are significantly related to the level of stress experienced by adolescents. Adolescents with mild physical violence are more prone to experiencing stress 2.655 times, and adolescents with severe psychological violence are more prone to experiencing stress by 6.285 times.

This finding contributed significantly to providing information related to the relationship between physical and psychological violence incidents with the stressful incidence in dating adolescents during the COVID-19 pandemic. The results reported can be used as material for evaluation and policymaking by stakeholders. However, this research is still limited to quantitative analysis due to pandemic conditions. The researcher suggests that further research focuses on qualitative analysis through in-depth interviews to obtain more comprehensive information.

\section{REFERENCES}

[1] N. Liu et al., "Traumatic Experiences and PTSD Symptoms in the Chinese Male Intrafamilial Physical Violence Perpetrators: A Comparative and Structural Equation Modeling Study," J. Interpers. Violence, vol. 36, no. 5-6, pp. 2841-2861, 2018, doi: 10.1177/0886260518764103.

[2] World Health Organization, "Violence Against Women," 2017.

[3] R. Prakash et al., "Effect of physical violence on sexually transmitted infections and treatment seeking behaviour among female sex workers in Thane District, Maharashtra, India," PLoS One, vol. 11, no. 3, pp. 1-19, 2016, doi: 10.1371/journal.pone.0150347.

[4] R. Zahl-Olsen, N. Gausel, A. Zahl-Olsen, T. B. Bertelsen, A. T. Haaland, and T. Tilden, "Physical Couple and Family Violence Among Clients Seeking Therapy: Identifiers and Predictors," Front. Psychol., vol. 10, no. December, pp. 1-11, 2019, doi: 10.3389/fpsyg.2019.02847.

[5] C. N. Devi, "Dating Violence (Case Study of Students Who Have Committed Dating Violence), (In Indonesia: Kekerasan Dalam Pacaran (Studi Kasus pada Mahasiswa yang pernah melakukan Kekerasan Dalam Pacaran)," Universitas Negeri Yogyakarta, 2015.

[6] The Ministry of Women's Empowerment and Child Protection, "Beware of the Danger of Dating Violence (In Indonesia: Waspada Bahaya Kekerasan dalam Pacaran)," Kementrian Pemberdayaan Perempuan dan $\begin{array}{llll}\text { Perlindungan } \quad \text { Anak, } 2018 . & \text { [Online]. }\end{array}$ https://www.kemenpppa.go.id/index.php/page/read/31/1669/waspada-bahaya-kekerasan-dalam pacaran\#: :text=Berbagai dampak yang ditimbulkan dari,1\%2C5 kali lebih banyak

[7] Komnas Perempuan, "Victims Voiced, Data Talks to Pass the Bill on the Elimination of Sexual Violence as the State of Commitment: A Record of Violence against Women (In Indonesia: Korban Bersuara Data Bicara Sahkan 
RUU Penghapusan Kekerasan Seksual sebagai Wujud Komitmen Negara: Catatan Kekerasan Perempuan," Catatan Tah. Tentang Kekerasan Terhadap Peremp., p. 123, 2019.

[8] Bappeda Prov Yogyakarta, "Data on the number of violence against women and children by age group and location (In Indonesia: Data Jumlah Kekerasan Terhadap Perempuan dan Anak Menurut Kelompok Umur dan Lokasi)," 2019, [Onlie]. Available: http://bappeda.jogjaprov.go.id/dataku/data_dasar/index/638-jumlah-kekerasan-terhadapperempuan-dan-anak-menurut-kelompok-umur-dan-lokasi

[9] S. M. Ayu, M. Hakimi, and E. N. Hayati, "Dating Violence and Anxiety of Young Women in Purworejo Regency," J. Kesehat. Masy. (Journal Public Heal.), vol. 6, no. 1, pp. 61-74, 2013, doi: 10.12928/kesmas.v6i1.1067.

[10] I. Suwartika, A. Nurdin, and E. Ruhmadi, "Analysis of Factors Related to Academic Stress Levels of Regular Students in Nursing D III Study Program Cirebon Health Polytechnic Ministry of Health, Tasikmalaya (In Indonesia: Analisis Faktor Yang Berhubungan Dengan Tingkat Stress Akademik Mahasiswa Reguler Program Studi D Iii Keperawatan Cirebon Poltekkes Kemenkes Tasikmalaya)," Soedirman J. Nursing, vol. 9, no. 3, pp. 173189, 2014.

[11] M. Dosil, J. Jaureguizar, E. Bernaras, and J. Burges Sbicigo, "Teen dating violence, sexism, and resilience: a multivariate analysis," Int. J. Environ. Res. Public Health, vol. 17, no. 8, 2020, doi: 10.3390/ijerph17082652.

[12] L. Nasrani and S. Purnawati, "Differences in Stress Levels Between Men and Women on Yoga Participants in Denpasar City (In Indonesia: Perbedaan Tingkat Stres abtara Laki-laki dan Permpuan pada Peserta Yoga di Kota Denpasar)" J. Med. Udayana, vol. 4, no. 12, 2015.

[13] G. IM, B. M. Bacon A, C. T, and H. J, "Serotonin Transporter Genotype, Morning Cortisol and Subsequent Depression In Adolescents,” Br. J. Psychiatry, vol. 195, no. 1, pp. 39-45, 2009, doi: 10.1192/bjp.bp.108.054775.

[14] N. W. Asfiana, "Relationship between Income Level and Stress Level of Head of Family in Dukuh Klie, Karangasem Village, Bulu District, Sukoharjo Regency (In Indonesia: Hubungan Tingkat Penghasilan Dengan Tingkat Stres Kepala Keluarga Penduduk Dukuh Klie Desa Karangasem Kecamatan Bulu Kabupaten Sukoharjo)," Skripsi, Universitas Muhammadiyah Surakarta, 2015.

[15] M. Muñiz-Rivas, M. Vera, and A. Povedano-Díaz, "Parental style, dating violence and gender," Int. J. Environ. Res. Public Health, vol. 16, no. 15, 2019, doi: 10.3390/ijerph16152722.

[16] S. Dorrington et al., "Trauma, post-traumatic stress disorder and psychiatric disorders in a middle-income setting: prevalence and comorbidity," Br. J. Psychiatry, vol. 205, no. 5, pp. 383-389, 2014, doi: 10.1192/bjp.bp.113.141796.

[17] S. Januwarsih and N. J. Triastuti, "Relationship Between Education Level, Income, Tahajud Prayers and Recreation with Parental Stress of Autistic Sufferers (In Indonesia: Hubungan Antara Tingkat Pendidikan, Pendapatan, Salat Tahajud dan Rekreasi dengan Stres Orang Tua dari Penderita Autis)," In Proceeding Book Call for Paper Thalamus: Medical Research For Better Health, Universitas Muhammadiyah Surakarta, 2020, pp. 444-456.

[18] American Psychologist Association, "Managing your stress in tough economic times Use these tips to help deal with stress about money and the economy," American Psychologist Association, 2010. [Online]. Available:https://www.apa.org/topics/economic-stress

[19] M. E. Karlsson, M. Calvert, R. W. Juventino Hernandez Rodriguez, and J. R. Temple5, "Changes in Acceptance of Dating Violence and Physical Dating Violence Victimization in a Longitudinal Study with Teens," Child Abus. Negl., vol. 86, no. 270, pp. 123-135, 2019, doi: 10.1016/j.chiabu.2018.09.010.Changes.

[20] G. Ontiveros, A. Cantos, P. Y. Chen, R. Charak, and K. D. O’Leary, "Is All Dating Violence Equal? Gender and Severity Differences in Predictors of Perpetration," Behav. Sci. (Basel)., vol. 10, no. 7, 2020, doi: 10.3390/BS10070118.

[21] R. F. Damopoli et al., "The Relationship between Violence and Work Stress in Emergency Care Unit Nurses and Hospital Intensive Care Units in Bitung City and North Minahasa Regency (In Indonesia: Hubungan Kekerasan Dengan Stres Kerja Pada Perawat Unit Gawat Darurat Dan Intensive Care Unit Rumah Sakit Di Kota Bitung Dan Kabupaten Minahasa Utara)," J. Kesmas, vol. 8, no. 3, pp. 50-59, 2019.

[22] S. H. Hamaideh, "Occupational stress, social support, and quality of life among Jordanian mental health nurses," Issues Ment. Health Nurs., vol. 33, no. 1, pp. 15-23, 2012, doi: 10.3109/01612840.2011.605211.

[23] W. A. Safitri, “The Impact Of Violence In Dating, (In Indonesia: Dampak Kekerasan Dalam Berpacaran)," Artik. Ilm. Has. Penelit. Mhs. UNEJ, vol. 1, no. 1, pp. 1-6, 2013.

[24] P. E. Haes, "Violence of teenagers in dating violence in denpasar city in the perspective of symbolic interaction analysis (In Indonesia: Kekerasan pada Remaja Perempuan dalam Masa Pacaran ......(Putri Ekaresty Haes)," Jurnal Ilmiah Dinamika Sosial, vol. 1, no. 2. pp. 166-176, 2017.

[25] H. Chigiji et al., "Risk factors and health consequences of physical and emotional violence against children in Zimbabwe: A nationally representative survey," BMJ Glob. Heal., vol. 3, no. 3, pp. 1-12, 2018, doi: 10.1136/bmjgh-2017-000533.

[26] S. M. Ayu, L. Sofiana, and F. U. Jayanti, "The correlation of teacher's role, peers, and mass media with the incidence of dating violence in adolescents at SMK Piri 1 Yogyakarta," Int. J. Community Med. Public Heal., vol. 6, no. 6, p. 2325, 2019, doi: 10.18203/2394-6040.ijcmph20192292.

[27] J. Elmquist et al., "A Gender Comparison of Motivations for Physical Dating Violence Among College Students," J Interpers Violence, vol. 31, no. 1, pp. 186-203, 2016, doi: 10.1177/0886260514555130.A. 